Paedagogia Christiana

2/28 (20I I) - ISSN 1505-6872

Mieczystaw Ozorowski*

Warszawa

\title{
Bóg a stworzenie w teologii katolickiej
}

Prawda o stworzeniu świata i człowieka należy do podstawowych prawd wiary katolickiej. Kościół naucza, że Bóg jest Stwórcą wszystkiego, co istnieje, nieba i ziemi, istot niebieskich i ziemskich. Nauka o stworzeniu zawarta jest już na pierwszych kartach Księgi Rodzaju, ale jej pełnię objawia dopiero przyjście na świat Syna Bożego. Prawda o stworzeniu jest bowiem ściśle związana z prawdą o zbawieniu.

Nauka o stworzeniu świata i człowieka posiada pierwszorzędne znaczenie. Odnosi się ona do podstaw ludzkiego życia. Odpowiada ona na podstawowe pytania, jakie stawiają sobie wszyscy ludzie: „Skąd pochodzimy?”, „Dokąd idziemy?”, „Jaki jest nasz początek?”, „Jaki jest nasz cel?”, „Skąd pochodzi i dokąd zmierza wszystko, co istnieje?" (KKK 282). Pytania o początek, o cel i o sens naszego ludzkiego życia łączą się nierozłącznie i decydują o kierunku i naszego życia, i działania.

Kościół zdaje sobie sprawę, że na postawione wyżej pytania ludzie próbują odpowiedzieć od wieków przy pomocy różnych systemów religijnych, filozoficznych i naukowych. Odkrycia naukowe oraz dokonany postęp w tej dziedzinie wzbudzają u ludzi wierzących podziw i zachwyt nad Mądrością Stwórcy (Mdr 7, 17-21). Nauka Kościoła na temat stworzenia jest bogata i posiada duży dorobek teologiczny ${ }^{1}$.

* Ks. dr hab. Mieczysław Ozorowski, prof. UKSW, kierownik Katedry Historii Teologii Małżeństwa i Rodziny na Wydziale Studiów nad Rodziną Uniwersytetu Kardynała Stefana Wyszyńskiego w Warszawie.

${ }^{1}$ K. Medard, I widziat Bóg, że to jest dobre: teologia stworzenia, Poznań 2008; J. Warzeszak, Człowiek w obliczu Boga i pośród stworzenia, Warszawa 2005. M. Kowalczyk, 
Wiedza, która wynika z chrześcijańskiej prawdy o stworzeniu, dotyczy najistotniejszych prawd, takich jak: ,prawdy o stworzeniu, jego początku i jego celu w Bogu, jego uporządkowaniu i jego dobroci, o powołaniu człowieka, a w końcu prawdy o dramacie grzechu i nadziei zbawienia" (KKK 289).

\section{Stwórcze Słowo Boga}

Księga Rodzaju wskazuje nam, że Bóg stwarza poprzez swoje wszechmocne Słowo. Wyrażenie „A potem Bóg rzekł...” powtarza się w niej jak refren kilka razy. Prawdę tę potwierdzają inne księgi Starego i Nowego Testamentu. Autor Księgi Mądrości modli się słowami: „Ty Boże moich ojców, który wszechświat stworzyłeś swoim Słowem...” (Mdr 9, 1). Podobnie modli się Psalmista: „Przez Słowo Pana powstały niebiosa i wszystkie ich zastępy przez tchnienie ust Jego..." (Ps 33, 6-9). Nowy Testament jeszcze dobitniej artykułuje tę prawdę (2 P 3, 5; Jk 1, 18; Rz 1, 8; 4, 17; Hbr 1, 3). Najpiękniejszy przykład znajdziemy na początku Ewangelii św. Jana: „Na początku było Słowo... i Bogiem było Słowo... Wszystko przez Nie się stało, a bez Niego nic się nie stało" (J 1, 1-3).

Hebrajski termin dabar oznacza, że w Bogu ukryta jest moc działania, która pragnie się objawić. Słowo Boże posiada niezwykły dynamizm i moc działania. Ono jest jak ogień i jak młot kruszący skałę (Jr 23, 29). Niewątpliwie Izraelczycy doświadczyli w swoich dziejach błogosławionego działania Słowa Bożego. Swoją zaś historię traktowali jako odpowiedź na objawione Słowo Boga, które naocznie widzieli, jak przemienia się w konkretne czyny. Objawienie Boże to przecież słowa i czyny wzajemne ze sobą powiązane (KO 1). Słowo to jest wyrazem woli Bożej. Jest to suwerenny i osobowy sposób działania Boga. Słowo nie jest wynikiem jakiegoś fatum, przypadku lub naturalnej siły wyższej. Całe stworzenie jawi się jako słowo Boże skierowane do człowieka, który potrafi je zobaczyć, usłyszeć i odczytać. Ojcowie Kościoła mówili, że świat jest pieśnią, natura jest księgą, przez którą Bóg przemawia do nas.

Świat został stworzony dla człowieka, który jako jedyny potrafi podziwiać i zachwycać się stworzeniem. Człowiek stał się partnerem boskiego dialogu przy stworzeniu. Bóg powierza człowiekowi pieczę nad ziemią, aby ją zaludnił i uczynił sobie poddaną (Rdz 1, 28-29). Człowiek naśla-

Z. Danielewicz, Traktat o stworzeniu. Traktat o rzeczywistości ostatecznej, Warszawa 2007;

I. Czaczkowska, Pomiędzy potopem a tęczą. Ekumeniczne studium integralności stworzenia, Lublin 1998. 
duje Stwórcę, nadając wszelkim istotom żywym konkretną nazwę (Rdz 2, 19-20). Biblia wskazuje na swoisty antropocentryzm stworzenia. Osobowy Bóg zwraca się do człowieka, jedynej osoby stworzonej, która uosabia świat. Człowiek jest wezwany, aby w sposób osobowy, rozumny i wolny odpowiedzieć Bogu na jego wezwanie. Człowiek jako jedyny w imieniu całego stworzenia jest zdolny dać Bogu satysfakcjonującą odpowiedź. Jest to początek dialogu człowieka z Bogiem oraz dialogu między ludźmi.

\section{Trynitarny wymiar dzieła stworzenia}

Współcześnie przypomina się nieustannie, że stworzenie jest dziełem całej Trójcy Przenajświętszej. Bogu Ojcu przypisuje się tradycyjnie działanie stwórcze, ale wszystkie Osoby Boskie biorą w nim udział. Niewątpliwie, wszystko pochodzi od Boga Ojca przez Syna w Duchu Świętym. Bóg Ojciec daje początek temu wszystkiemu, co istnieje poza Nim (KKK 290). Tę prawdę wyznajemy w każdą niedzielę, wypowiadając symbol wiary Soboru nicejsko-konstantynopolitańskiego, gdy mówimy: „wierzę w Boga Ojca wszechmogącego, Stworzyciela nieba i ziemi”. Stworzenie jest podstawowym objawieniem wszechmocy Boga oraz znakiem niczym nieuwarunkowanego panowania Ojca. Trynitarny wymiar chrześcijanie od początku odnajdywali w formule liczby mnogiej, jaka jest używana przez redaktora pierwszego opisu stworzenia w Księdze Rodzaju: „A wreszcie rzekł Bóg: Uczyńmy człowieka na Nasz obraz, podobnego Nam" (Rdz 1, 26).

Nowy Testament wielokrotnie zwraca uwagę, że świat został stworzony przez Syna (1 Kor 6, 8; Kol 1, 16; Hbr 1, 2; J 1, 3. 10; 1 Kor 6, 8; Hbr 1, 2). Najdobitniejsze słowa znajdujemy w Prologu do Ewangelii św. Jana: „Na początku było Słowo... i Bogiem było Słowo... Wszystko przez Nie się stało, a bez Niego nic się nie stało" (J 1, 1-3). Bóg Ojciec stworzył wszystko przez swojego umiłowanego Syna - odwieczne Słowo (KKK 291). Syn nie jest tylko narzędziem stworzenia, ale sam jest Stwórcą, ponieważ jest współistotny Bogu Ojcu. Wszystko jest stworzone przez Syna i dla Syna (Kol 1, 16-17). Stworzenie świata zostało ukierunkowane na Chrystusa Zbawiciela.

Wiara Kościoła wskazuje, że Duch Święty, jako Pan i Ożywiciel, podejmuje również działanie stwórcze ${ }^{2}$. Stary Testament zapowiada to stwórcze działanie Ducha między innymi w słowach: „Duch Boży unosił się nad wo-

${ }^{2}$ Hymn Veni, Creator Spiritus wyznaje, że jest On „Duchem Stworzycielem”, „Źródłem wszelkiego dobra". 
dami” (Rdz 1, 2) albo „Duch Pański napełnia okręg ziemi” (Mdr 1, 7). Duch Święty jest uważany za zasadę miłości w stworzeniu świata ${ }^{3}$.

Nauka o trynitarnym wymiarze dzieła stworzenia znalazła uznanie u wielu teologów począwszy od starożytności. Św. Ireneusz wyznaje, że suwerenny Bóg urzeczywistnił swój plan stworzenia „swymi własnymi rękoma", to jest poprzez swego Syna i Ducha Świętego ${ }^{4}$. Św. Augustyn twierdził, że całe stworzenie nosi ślady Trójcy Świętej i posiada strukturę trynitarną Według Tomasza stwarzanie jest aktem całej Trójcy Świętej, a stworzenie stoi w ścisłym związku z życiem trynitarnym. Bóg Ojciec jest Stworzycielem, jak ten, który nie pochodzi od nikogo. On Stwarza przez Syna, przez odwieczne poznanie, podobnie jak przekazuje swoją naturę przez Syna Duchowi Świętemu. Duch Święty, jako ten, który ma moc od obydwu, jest Panem i Ożywicielem, czyli zarządza i ożywia to wszystko, co stworzył Ojciec przez Syna ${ }^{6}$.

\section{Miłość i chwała Boża motywami stworzenia}

Kościół nie przestaje przypominać, że świat został stworzony dla chwały Bożej. Stwórca nie uczynił świata dla powiększenia swojej chwały, ponieważ jest ona pełna i doskonała, ale aby ją objawić i nią się podzielić ze stworzeniem. Bóg w żaden sposób nie był przymuszony ani zdeterminowany, aby dokonać aktu stwórczego. Jako istota transcendentna, Bóg dokonał tego w całkowitej wolności: „Nasz Bóg jest wielki, czyni wszystko, co zechce” (Ps 115, 3). Świat jawi się jako autonomiczny a jednocześnie całkowicie zależny od Stwórcy. Ani Bóg nie udoskonala się stwarzając świat, ani świat nie emanuje $\mathrm{z}$ Boga.

Stworzenie jest objawieniem się miłości Boga. Wolność objawia się przede wszystkim w dawaniu. Bóg stwarzając świat objawia swoją bezgra-

3 Tomasz z Akwinu, STh I, q. 37: „Nie tylko Syna, ale także Siebie i nas Ojciec miłuje Duchem Świętym, gdyż jak powiedzieliśmy, «miłować» jako znamię nie oznacza tylko wydawanie Boskiej Osoby, ale i Osobę wydaną na sposób miłości, która to miłość wyraża związek z rzeczą miłowaną. Stąd to: jak Ojciec «mówi» Siebie i wszystko stworzenie Słowem, które zrodził, a to dlatego, że Słowo zrodzone w pełni przedstawia Ojca i wszystko stworzenie, tak samo również «miłuje» Siebie i wszystko stworzenie Duchem Świętym, a to dlatego, że Duch Święty pochodzi jako miłość tej pierwszej dobroci, według której Ojciec miłuje Siebie i wszystko stworzenie. Widać również z tego, że ów związek ze stworzeniem poniekąd drugorzędowo zawiera się i w Słowie, i w Miłości pochodzącej, mianowicie o ile prawda i dobroć Boża są początkiem poznania i miłowania wszystkiego stworzenia".

${ }^{4}$ Św. Ireneusz, Adversus haereses 4, 20, 1.

5 A. Ganoczy, Nauka o stworzeniu, Kraków 1999, s. 86-87.

${ }^{6}$ Tomasz z Akwinu, STh, I, q.45. 
niczna dobroć i miłość. Stworzenie wynika z Jego mądrości, wolności i Jego miłości (KKK 295). Bóg chce dobra człowieka i pełnego jego rozwoju. Bóg stworzył świat, aby dać udział w chwale i miłości Boga. Motywem stworzenia świata jest danie mu udziału w swej chwale i miłości. Równocześnie wyrażamy przez to prawdę, że dzieło stworzenia jest całkowicie wolnym aktem Boga; wyłącznie aktem Boga, a nie jakiegokolwiek stworzenia.

Celem świata stworzonego jest udział w chwale Boga. Przypominają o tym liczne Psalmy: „Niebiosa głoszą chwałę Boga, dzieło rąk Jego nieboskłon obwieszcza" (Ps 19, 2). Świat sławi i chwali swego Stwórcę. Tradycja określa to w ten sposób: świat został stworzony dla chwały Bożej (per gloriam Dei). Dla człowieka, umiejącego odczytywać znaki czasu, całe stworzenie jest objawieniem się dobroci i doskonałości Boga. W Nowym Testamencie pojęcie «chwały Bożej» nabiera charakteru chrystologicznego ( 2 Kor 4, 4; 3, 18; Tt 2, 13; Hbr 1, 3). Chwała Boża w pojęciu biblijnym oznacza objawienie się dobroci i zbawienia, które definitywnie dokonało się w Jezusie Chrystusie. Stworzenie, wychodząc z dobroci Boga, jest wezwane do uczestniczenia w Jego dobroci: „A Bóg widział, że wszystko, co uczynił, było dobre... bardzo dobre": (Rdz 1, 4. 10. 12. 18. 21. 31). Stworzenie jest chciane przez Boga i ofiarowane jako bezinteresowny dar przekazany dla człowieka, jako jego dziedzictwo (KKK 299).

Stworzenie na chwałę Bożą oznacza udział w doskonałości Boga. Chwała Boża powoduje rozwój oraz wzrost podobieństwa i obrazu Jego dobroci w człowieku. List do Rzymian przypomina: ,skoro wspólnie z Nim cierpimy po to, by też wspólnie mieć udział w chwale" (Rz 8,17). Niestety, grzech pierworodny pozbawił nas, ludzi, udziału w chwale Bożej (Rz 3, 23). Odkupienie Chrystusowe przywraca człowiekowi dostęp do tej chwały. Człowiek może uczestniczyć w chwale Chrystusa, jeśli uczestniczy w Jego krzyżu i zmartwychwstaniu.

Bóg, stwarzając świat, chciał, aby stworzenie odwzajemniło się miłością. Człowiek staje się w pełni człowiekiem wówczas, gdy jest otwarty na Boga i gdy przyjmuje Jego miłość 7 . Człowiek doskonali się na tyle, na ile pozwala się Bogu udoskonalać. Bóg chce, by stworzenia Go wielbiły. Jednakże chce tego nie ze względu na siebie samego, ale ze względu na stworzenie; w celu jego samorealizacji. Oddawanie chwały Bogu należy do samourzeczywistnienia się bytów. Oddawanie chwały Bogu ukazuje się w najdoskonalszym stopniu, gdy Chrystus, Człowiek doskonały, uwielbia swego Ojca. Kościół uczestniczy w kapłańskiej funkcji Chrystusa, składając Bogu ofiarę uwielbienia (KK 12). Chrześcijanin ma szansę, spełniając rozmaite codzienne czynności,

7 Pisze o tym Jerzy Szymik w swoim artykule: Od amor do amo. Stworzenie-człowiekChrystus, w: A. Klupczyński (red.), Teologiczne odczytywanie stworzenia, Poznań 2008. 
uwielbiać nimi Boga. To oddawanie chwały Bogu osiąga szczyt w sakramencie Eucharystii. W celebracji eucharystycznej, w której chrześcijanin czyni dar ze swego życia, stając się ofiarą miłą Bogu, dary chleba i wina, owoce ziemi oraz pracy rąk ludzkich, symbol całego stworzenia, zostają bowiem przyjęte, aby stać się ciałem i krwią Chrystusa w dziele uwielbienia Ojca.

Oddawanie chwały Bogu jest najbardziej właściwą formą istnienia człowieka. Psalmy rozciągają powinność oddawania chwały Bogu na całe stworzenie. Każda istota stworzona ma oddawać chwałę Bogu i nic nie może przesłonić tego zaszczytnego obowiązku. „Niech żyje moja dusza i niech chwali Ciebie" (Ps 119, 175).

Tradycja chrześcijańska utrzymuje, że Bóg nie potrzebuje dla siebie świata, dlatego można powiedzieć, że świat został stworzony dla człowieka ${ }^{8}$. To samo wyraża średniowieczna formuła: propter hominem factus est mundus. Św. Tomasz z Akwinu zaś pisze: „Człowiek, jest celem całego stawania się świata”. Św. Ireneusz wyraził słynne swe stwierdzenie: „Chwałą Boga jest człowiek żyjący, życiem zaś człowieka jest oglądanie Boga” (Gloria enim Dei vivens homo vita autem hominis visio Dei), które jest przytaczane przez wielu teologów ${ }^{10}$.

\section{Stworzenie i czas}

Nauka Kościoła stwierdza, że Bóg stworzył świat wraz z czasem. Księga Rodzaju przypomina, że Bóg stworzył niebo i ziemię „na początku” (Rdz 1, 1). Świat posiada swój początek w czasie. Tylko Bóg jest odwieczny. Stwórczy akt Boga jest ponadczasową decyzją jego wolności, pochodzącą z Jego miłości. Także ze strony dzieła stworzenia nie może być mowy o początku w czasie, tak jakby świat miał być stworzony wcześniej czy później w przestrzeni czasowej, istniejącej wcześniej przed światem. Nie istnieje żaden czas poza światem czy przed światem. Nie można mówić o czasie, jeśli nie ma stworzenia, które podlega zauważalnym zmianom, a to oznacza, że świat rozpoczął swe istnienie wraz z czasem. Czas jest miarą trwania właściwego bytom materialnym. Prawda, że świat został stworzony na początku czasu, to znaczy posiada pierwszy moment swego istnienia, była wielokrotnie przypominana przez Magisterium Kościoła.

${ }^{8}$ Św. Justyn, Apol. I, 11.

9 Św. Tomasz z Akwinu, SCg. 3, 22.

${ }^{10}$ K. Medard, I widziat Bóg, że to jest dobre: teologia stworzenia, Poznań 2008; Św. Ireneusz, Adversus haereses, IV, 20, 7 
Objawienie Boże ukazuje się nam w kontekście historii zbawienia. Wszystko zmierza ku Chrystusowi, który przychodzi zbawić człowieka i odnowić całe stworzenie (Ef 1, 10). W tej wizji człowiek ukazuje się nie tylko jako centrum i szczyt stworzenia, ale jako ten, który jest powołany do ,przedłużenia dzieła Stwórcy” oraz do dania „osobistego wkładu do urzeczywistnienia planu opatrznościowego Boga w historii”. Człowiek jest powołany do współpracy z Bogiem, do wypełnienia stworzenia Bożego (KDK 67; 33-39; 54-57; KK 36). Biblia, wskazując na ujęcie historiozbawcze, ukazuje, że świat jest czasem i miejscem przymierza Boga ze swym ludem. To przymierze osiąga swój szczyt w Jezusie Chrystusie, który prowadzi ludzkość do jej ostatecznego wypełnienia. Świat stworzony przez Boga jest odpowiednio ukierunkowany. Biblia prezentuje określony porządek epok: czas patriarchów, czas prawa, czasy sędziów, królów, proroków i wreszcie pełnię czasów (Mk 1, 15), która ma swą godzinę w Jezusie Chrystusie (J 2, 4; 7, 6; 13, 1), czas Ewangelii, czas łaski. Chrystus jako Kyrios obejmuje panowanie Boga nad światem i nad narodami; prowadząc rozwój świata i ludzkości do końca i do wypełnienia (Ef 1, 10: „dla dokonania pełni czasów, aby wszystko na nowo zjednoczyć w Chrystusie jako Głowie”). Pomiędzy stworzeniem a paruzją jest czas zbawienia (kairos), który przybliża nas do ostatecznego eschatonu.

\section{Stworzenie z nicości}

Kościół wyznaje z mocą, że Bóg w dziele stworzenia nie potrzebował żadnej pomocy ani niczego, co istniałoby wcześniej. Ogólnie przyjmuje się tezę, że Bóg stwarza w sposób wolny „z niczego" - ex nihilo ${ }^{11}$. Sformułowanie o stworzeniu świata z nicości jest wyrażeniem syntetycznym i zawiera w sobie wiele treści, a przede wszystkim to, że świat poza Bogiem nie ma żadnej innej przyczyny. Pismo święte wielokrotnie przypomina tę prawdę. Wyraża to przede wszystkim hebrajskie słowo bara ' - stwarzać, które odnajdujemy na pierwszych stronach Księgi Rodzaju. Podmiotem tego słowa jest zawsze i wyłącznie Bóg. Inny wyraźny tekst znajdujemy w Drugiej Księdze Machabejskiej. W 2 Mach 7, 28 matka dodająca odwagi swemu synowi wobec męczeństwa mówi: „Proszę cię synu, spojrzyj na niebo i na ziemię, a mając na oku wszystko, co jest na nich, zwróć uwagę na to, że z niczego (nie z rzeczy istniejących)

${ }^{11}$ Sobór Laterański IV: DS 800; Sobór Watykański I: DS 3025. Cóż nadzwyczajnego byłoby w tym, gdyby Bóg wyprowadził świat z istniejącej już wcześniej materii? Ludzki twórca, gdy otrzyma materiał, zrobi z niego wszystko, co zechce. Tymczasem moc Boga okazuje się właśnie w tym, że wychodzi On od nicości, by uczynić wszystko, co zechce. Św. Teofil z Antiochii, Ad Autolycum, 2, 4: PG 6,1052 
stworzył je Bóg i że ród ludzki powstał w ten sam sposób". Obok stwierdzeń wprost mówiących o stworzeniu z nicości wskazać należy na te teksty biblijne, które mówią o Bogu jako o Stwórcy wszystkich rzeczy (por. J 1, 3; 1 Kor 8, 6; Rz 11, 36; Ef 3, 9; Kol 1, 16; Ap 4, 11: „Godzien jesteś, Panie i Boże nasz, odebrać chwałę i cześć, i moc, boś Ty stworzył wszystko, a dzięki Twej woli istniało i zostało stworzone").

Formuła ex nihilo pojawia się w utworze Pasterz Hermasa: „W pierwszym rzędzie wierz, że jest Bóg, który stworzył wszystkie rzeczy i uczynił je wszystkie z nicości”. Św. Ireneusz i Orygenes powołują się na ten tekst, który stał się dziedzictwem wiary, bronionej przeciwko wszelkim uproszczeniom filozoficznym typu dualistycznego czy emanacjonistycznego, a także przeciw pogardzie rzeczywistością materialną i cielesną, która jest obecna w gnozie. Prawdę tę potwierdził papież Leon Wielki w deklaracji przeciw manichejczykom (447 r.), podobnie także sobory średniowiecza (Laterański IV - 1215 r., Lioński II - 1274 r., Florencki - 1442 r.). Sobór Watykański I powtórzył definicję soboru Laterańskiego IV, opisując stworzenie jako spowodowanie zaistnienia rzeczy z niczego, według całej ich substancji (DS 3025).

Wszystko, co istnieje, zawdzięcza swoje istnienie wszechmocy Bożej. Wyrażenie, że Bóg stworzył świat z niczego, jest konsekwencją stwierdzenia Jego wszechmocy. Formuła stworzenia ex nihilo oznacza, że stworzenia nie poprzedza jakaś inna rzeczywistość ani chaos. Do dzieła stworzenia Bóg nie potrzebuje pomocy ani uprzednio istniejącej „,materii”. Nie istnieje nic między światem a Bogiem, co byłoby jakąkolwiek przyczyną sprawczą świata. Formuła „stworzenie z nicości” jest negatywnym sposobem wyrażenia prawdy, że Bóg jest autorem całej rzeczywistości duchowej i materialnej.

Wyrażenie ex nihilo wskazuje na immanencję Boga w świecie, to znaczy Bóg jest w świecie, ale też świat jest w Bogu. Świat nie jest wolny od Jego obecności i troski pełnej miłości (Ps 139, 7n). Rzeczywistość stworzona jest dla człowieka wezwaniem do spotykania Boga w świecie i do dania $\mathrm{Mu}$ adekwatnej odpowiedzi. Ze względu na to, że wszystko pochodzi z rąk Boga, dlatego nic nie stanowi przeszkody do tego spotkania. „W Nim żyjemy, poruszamy się i jesteśmy" (Dz 17, 28). Jak mówi św. Augustyn, Bóg jest wyższy od mojej wysokości i głębszy od mojej głębi ${ }^{12}$.

\section{Opatrzność Boża}

Opatrzność Boża łączy się ściśle z tematyką stworzenia, z tematem Boga, który objawia się jako Stwórca i Zbawiciel. Świat stworzony przez

12 Św. Augustyn, Wyznania, III, 6, 11. 
Boga nieustannie jest zależny od Niego w każdym momencie swego istnienia. On sam podtrzymuje świat $\mathrm{w}$ istnieniu mocą swojej stwórczej woli. Wizja świata, który dynamicznie się rozwija i przekształca, potrzebuje jeszcze bardziej miłującej i troskliwej obecności Boga. Kościół nazywa to zjawisko Opatrznością Bożą. Nauka ta posiada swoje głębokie uzasadnienie w Piśmie świętym Starego i Nowego Testamentu. Izraelici wierzyli, że obecność Boga jest nieustannie konieczna w każdym momencie istnienia świata. To Bóg zabija i ożywia (1 Sm 2,6), to On daje deszcz, zbiory i pokarm we właściwym czasie (Jr 5, 24; Ps 145, 15). To On daje pory roku i pory dnia (Ps 74,16$)$. W Księdze Mądrości czytamy: „Miłujesz bowiem wszystkie stworzenia, niczym się nie brzydzisz, co uczyniłeś, bo gdybyś miał coś w nienawiści, byłbyś tego nie uczynił. Jakżeby coś trwać mogło, gdybyś tego nie chciał? Jakby się zachowało, gdybyś tego nie wezwał? Oszczędzasz wszystko, bo to wszystko Twoje, Panie, miłośniku życia!" (Mdr 11, 24-26).

Bóg miłuje swoje stworzenie i pomimo grzechów popełnionych przez ludzi nie rezygnuje z przyjaźni i troski nad nimi (Pwt 7, 9; Iz 49, 7; 53, 3). $Z$ tego względu Bóg zawiera kolejne przymierza $\mathrm{z}$ ludźmi, dając im gwarancję swojej opieki. Momentem kulminacyjnym tej historii troski i zbawienia człowieka była śmierć i zmartwychwstanie Jezusa (J 11, 49n). Izraelici doświadczali opieki Boga, który zawarł z nimi przymierze, doświadczali Jego absolutnej mocy, widzieli, jak Bóg kieruje losami wszystkich ludzi i narodów. „Gdy podniesiesz oczy ku niebu i ujrzysz słońce, księżyc i gwiazdy, i wszystkie zastępy niebios, obyś nie pozwolił się zwieść, nie oddawał im pokłonu i nie służył, bo Bóg twój Jahwe, przydzielił je wszystkim narodom pod niebem" (Pwt 4, 19). Bóg wykorzystuje wszystko dla swych celów. Nawet upadek człowieka jest przyczynkiem do jego zbawienia. Również przeciwne Bogu moce są wykorzystane według woli Bożej (Rdz 20, 26; Wj 2). Opatrznością Bożą są objęte nie tylko wielkie historyczne wydarzenia, ale również codzienne potrzeby poszczególnych ludzi. Opatrzność Boga ogarnia każdego pojedynczego człowieka, jak to czytamy w Psalmie: „Pan moim pasterzem, niczego mi nie braknie" (Ps 23).

Chrystus również mówi o Opatrzności Bożej, wspominając o ptakach niebieskich i o liliach polnych: „Przypatrzcie się ptakom w powietrzu: nie sieją ani żną i nie zbierają do spichrzów, a Ojciec wasz niebieski je żywi. Czyż wy nie jesteście ważniejsi niż one?" (Mt 6, 25-34). Jezus domaga się od wierzących dziecięcego zawierzenia Opatrzności Ojca niebieskiego: „Nie troszczcie się więc zbytnio i nie mówcie: co będziemy jeść? co będziemy pić?... Ojciec wasz niebieski wie, że tego wszystkiego potrzebujecie. Starajcie się naprzód o Królestwo Boga i o Jego sprawiedliwość, a to wszystko będzie wam dodane" (Mt 6, 31-33). Najwyższym aktem Opatrzności Bożej był krzyż Chrystusa, gdzie dokonało się odkupienie świata (Ef 3, 9-11). 
Wszechświat posiada swe trwanie w Chrystusie, pierworodnym wobec całego stworzenia, w którym wszystko zostało stworzone (Kol 1,16).

Wielu Ojców Kościoła od początku głosiło naukę o Opatrzności Bożej, zwalczając i krytykując poglądy gnostyckie i stoickie, które były związane z predestynacją i fatalizmem. Św. Ireneusz ukazywał porządek kosmiczny w perspektywie objawienia się zbawienia Boga. Zaś Klemens Aleksandryjski widział Opatrzność Bożą jako funkcję Logosu, który jawił się jako pedagog wobec ludzkości. Poza tym rozumiał on zachowanie kosmosu jako kontynuację stworzenia. Dla św. Atanazego Logos był właściwą siłą Opatrzności i podtrzymywania świata w istnieniu. Św. Jan Chryzostom zwrócił uwagę, że także cierpienie i zło odnajdują swój sens w Opatrzności Bożej. Dzieło De civitate Dei Augustyna jest wielką apologią Opatrzności Boga. Scholastyka uzasadniała naukę o Opatrzności, odwołując się nie tyle do nauki o stworzeniu, co do istotowych przymiotów Boga, do Jego poznania i woli ${ }^{13}$.

Działanie Opatrzności Bożej nie ogranicza działania człowieka i innych stworzeń, ale jest u jego podstaw ${ }^{14}$. Bóg stoi u podstaw ludzkiej wolności. To On sprawia, że człowiek jest w swoim działaniu kimś wolnym. Osoba ludzka jest kimś autonomicznym w swej wolności. Św. Paweł wyznaje: „,wszystko mogę w tym, który mnie umacnia. Bóg jest w swej miłości sprawcą chcenia i działania" (Flp 2, 13; 4, 13). Jednakże wolność człowieka nie ogranicza wszechmocy Boga. Wszechmoc Boga objawia się w najwyższym stopniu w stworzeniu podmiotów wolnych i podtrzymujących ich wolne działanie. Stworzyciel daje ludziom możliwość dobrowolnego uczestniczenia w swojej Opatrzności, powierzając im odpowiedzialność za czynienie sobie ziemi poddanej. Człowiek może się stać współpracownikiem Opatrzności poprzez swoje działania, przez swoje modlitwy, a także przez swoje cierpienia (KKK 307).

Największym problemem ze zrozumieniem Opatrzności Bożej jest wythumaczenie problemu zła i cierpienia. Zło i cierpienie nigdy nie mogą być chciane przez Boga, a z drugiej strony dokonują się one w obecności Boga. Człowiek w swojej wolności jest odpowiedzialny za swe czyny tak złe, jak i dobre. Chrześcijańska odpowiedź na przyczyny zła w świecie nie jest ani łatwa, ani prosta, znajduje się ona w jego pełnym i integralnym przekazie. Katechizm Kościoła Katolickiego wskazuje, że obok „fizycznego dobra” istnieje też „fizyczne zło”, które jest związane z rozwojem i doskonaleniem się świata. Doskonalsze stworzenia zastępują te, które są mniej doskonałe

13 D. Chardonnens, Dei providentia circa hominem: providence divine et condition humaine selon l'»Expositio super Iob ad litteram» de Thomans d'Aquin, Paris 1997.

${ }^{14}$ J.-B. Saint-Jure, Zaufanie Opatrzności Bożej: źródło pokoju i szczęścia, Warszawa 2009. 
(KKK 311). Istnieje również „zło moralne”, którego Bóg nigdy nie chce, a które jest skutkiem wolnych wyborów, dokonanych przez wolne osoby. Bóg więc dopuszcza istnienie pewnego zła, cierpienia i śmierci. Jednakże Bóg w swojej wszechmocnej Opatrzności może wyprowadzić dobro ze skutków nieszczęścia i zła, nawet moralnego, spowodowanego przez Jego stworzenia (KKK 312). Drogi Opatrzności są dla ludzi niezgłębionym misterium, które poznamy dopiero w rzeczywistości eschatologicznej, gdy skończy się nasze poznanie fragmentaryczne, gdy zobaczymy Boga „twarzą w twarz” (1 Kor 13, 12).

\section{Stworzenie człowieka}

Bóg umieścił człowieka na szczycie stworzenia i sprawił, że zajmuje on w tym świecie miejsce wyjątkowe. Jako stworzenie rozumne i duchowe jest partnerem samego Boga. Człowiek jest jedynym stworzeniem, którego Bóg chciał dla niego samego (KDK 24). Jest to również jedyne stworzenie, które jest zdolne do poznania i miłowania swego Stwórcy (KDK 12). Wyjątkowość człowieka polega na tym, że został on stworzony „na obraz Boży” (Rdz 1, 26-27). W encyklice Evangelium vitae Jan Paweł II wskazał, że

w opisie biblijnym odrębność człowieka od innych istot stworzonych jest podkreślona zwłaszcza przez fakt, że tylko jego stworzenie zostaje przedstawione jako owoc specjalnej decyzji Boga i Jego postanowienia, by połączyć człowieka ze Stwórcą szczególną i specyficzną więzią (Rdz 1, 26). Życie ofiarowane przez Boga człowiekowi jest darem, dzięki któremu Bóg udziela coś z siebie stworzeniu. [...] Człowiek zostaje obdarzony najwyższą godnością, która jest zakorzeniona w wewnętrznej więzi łączącej go ze Stwórcą: jaśnieje w nim odblask rzeczywistości samego Boga (nr 34).

Na mocy tego podobieństwa Bożego człowiek znajduje się w przestrzeni religijnej i może odnaleźć siebie jedynie w spotkaniu z Bogiem. Jest to najważniejszy przekaz prawdy o stworzeniu człowieka, niezależnie o ,sposobu" stworzenia (kreacjonistycznego czy ewolucyjnego) ${ }^{15}$.

Dzięki temu, że człowiek jest stworzony na obraz Boży, posiada on godność osoby. Nie jest on już czymś, ale kimś. Tylko on jest zdolny do poznania siebie i do panowania nad sobą. Tylko on jest zdolny do złożenia dobrowolnego daru z siebie oraz do utworzenia wspólnoty z innymi osobami

${ }^{15}$ C. Montenat, P. Roux, L. Plateaux, Odkrywanie stworzenia w ewolucji, Poznań 1993. 
(KKK 357). Bóg stworzył świat ze wszystkim, co na nim istnieje, dla człowieka. Ale on sam został stworzony, aby służyć Bogu i kochać Go oraz by ofiarować Mu całe stworzenie. To podobieństwo do Boga, w swej istocie, nie może być zniszczone czy zatracone przez grzech. Jest to element determinujący samo bycie człowiekiem i należy do istotowej integralności człowieka. To podobieństwo może jednakże ulec zniekształceniu w człowieku, który postępuje niestosownie do obrazu Bożego i dopuszcza się grzechu, który jest nadużyciem wolności i buntem przeciw Bogu (KDK 13). Grzesznik jest niezdolny do przeciwstawienia się atakom zła i dlatego doznaje pomniejszenia swego człowieczeństwa. Jednakże człowiek grzeszny i oddalony od Boga nie znajdzie pokoju serca, dopóki to podobieństwo nie zostanie odnowione w Chrystusie, ,nowym człowieku” (KDK 22).

Prawda o obrazie Boga w człowieku stanowi podstawę społecznej natury człowieka, która realizuje się przede wszystkim we wspólnocie mężczyzny i kobiety. Obraz Boży w człowieku ukazuje się w zróżnicowaniu płciowym, czyli ukierunkowaniu na drugą osobę, w przeznaczeniu do utworzenia komunii osób. Istotowa relacyjność, wpisana przez Boga w naturę mężczyzny i kobiety, wyznacza im zadanie budowania społeczności wolnej od podziałów (por. Kol 3,11), aby stanowić jedno w Chrystusie (Ef 2, 14), który burzy mury podziałów i stwarza w sobie jednego, nowego człowieka, dając podstawę nowych i trwałych relacji odnowionej ludzkości.

Od początku mężczyzna i kobieta zostali powołani, aby istnieć jedno dla drugiego (Mulieris dignitatem 7). Papież Jan Paweł II podkreślał konieczność wzajemnej pomocy ukierunkowanej na ciągłe odkrywanie i realizację bogactwa własnego człowieczeństwa. Jedność dwojga (mężczyzny i kobiety) ukazuje on, jako wynikającą z dialektycznej integracji dwóch podmiotów, która prowadzi do odkrycia i pogłębienia własnej tożsamości. Mężczyzna i kobieta są osobami powołanymi do tworzenia swych osobowości we wzajemnej relacji, która jest tym bardziej autentyczna, im bardziej respektuje indywidualność każdego, ale umożliwia jej rozwój i ubogacenie we wzajemności, dzięki której staje się pełniej sobą.

Katechizm Kościoła Katolickiego podkreśla, że

mężczyzna i niewiasta są «stworzeni», to znaczy są «chciani przez Boga»: $\mathrm{z}$ jednej strony $\mathrm{w}$ doskonałej równości, jako osoby ludzkie, a $\mathrm{z}$ drugiej strony w ich odnośnym byciu mężczyzną i niewiastą. „Być mężczyzną”, „być niewiastą" jest rzeczywistością dobrą i chcianą przez Boga: mężczyzna i niewiasta posiadają nienaruszalną godność pochodzącą bezpośrednio od Boga, ich Stworzyciela. Mężczyzna i niewiasta, z ich jednakową godnością, są „na obraz i podobieństwo Boże”. W ich „byciu mężczyzną” i „byciu niewiastą” ukazują mądrość i dobroć Stwórcy (KKK 369). 
Mężczyzna i niewiasta, stworzeni razem, są chciani przez Boga jedno dla drugiego (KKK 371). Nie oznacza to, że Bóg stworzył ich jako ludzi „w połowie” czy „niekompletnych”. Stworzył ich dla wspólnoty osób, w której każde z nich może być „pomocą” dla drugiego, ponieważ są jednocześnie równi sobie jako osoby („kość z moich kości...”) i uzupełniający się jako mężczyzna i niewiasta. W małżeństwie Bóg jednoczy ich w taki sposób, że „stają się jednym ciałem” (Rdz 2, 24), mogą przekazywać życie ludzkie: „Bądźcie płodni i rozmnażajcie się, abyście zaludnili ziemię" (Rdz 1,28). Przekazując życie swoim dzieciom, mężczyzna i niewiasta, jako małżonkowie i rodzice, współpracują w jedyny sposób z dziełem Stwórcy (KKK 372).

Relacje pomiędzy mężczyzną i niewiastą stanowią szczególny przykład społecznej natury człowieka. Sobór Watykański II ukazuje społeczną naturę człowieka w wymiarze życia rodzinnego, wspólnoty kościelnej, życia społecznego w kontekście miłości Boga Stwórcy (por. KDK 12; KK 41-42; DM 2; KDK 24). Ojcowie soborowi nauczają o społecznej naturze człowieka, jako o ,pewnym podobieństwie miedzy jednością Osób Boskich a jednością synów Bożych zespolonych w prawdzie i miłości” (KDK 24). Zakorzenienie wspólnoty ludzkiej we wspólnocie Osób Trójcy przenajświętszej stanowi kryterium krytycznej oceny przejawów życia społecznego, które opierają się tylko na władzy i przywilejach z pominięciem wymiaru wolności, który znajduje swoją realizację w służbie bliźnim.

Istotną konsekwencją idei stworzenia człowieka na obraz Boży w antropologii teologicznej jest specyficzny wkład w rozwiązywanie problemu ekologicznego ${ }^{16}$. Wielu obarcza chrześcijaństwo odpowiedzialnością za katastrofę ekologiczną, ponieważ opis stworzenia w Księdze Rodzaju $(\mathrm{Rdz} 1,28)$ przyznaje człowiekowi prawo do panowania nad ziemią. Tymczasem człowiekowi stworzonemu na obraz Boży zostaje powierzony los świata, ale nie jest on władcą absolutnym. Reprezentuje on tylko Boga na ziemi, jest tylko administratorem i opiekunem stworzenia. Otrzymane od Boga zadanie nie upoważnia go do rabowania i niszczenia świata, który został mu powierzony (por. Rdz 2, 7). Panowanie człowieka nad ziemią przypomina raczej pracę ogrodnika, który uprawia, strzeże i troszczy się o swój ogród. Nie ma tu miejsca na rabunek i niszczenie. Papież Jan Paweł II podkreślał w Evangelium vitae: „Człowiek został powołany, aby uprawiać ogród i strzec go $(\mathrm{Rdz} 2,15)$, jest zatem w szczególny sposób odpowiedzialny za

${ }^{16}$ I. Czaczkowska, Pomiędzy potopem a tęczq. Ekumeniczne studium integralności stworzenia, Lublin 1998; J. Dębowski, Ekologia osoby ludzkiej w chrześcijańskim nauczaniu społecznym, Olsztyn 2001. B. Jurczyk, Ekologia, człowiek, Kościót: antropologiczny wymiar kryzysu ekologicznego w ocenie Kościoła, Opole 2002. 
środowisko życia, to znaczy za rzeczywistość stworzoną, która z woli Boga ma służyć jego osobowej godności i jego życiu: odpowiedzialny nie tylko wobec obecnej epoki, ale i przyszłych pokoleń" (nr 42).

Człowiek staje się strażnikiem przyrody wówczas, gdy uznaje, że jest ona darem miłości Bożej. Autentyczna troska człowieka o świat stworzony jest nieodłącznie związana ze służbą człowieka wobec Boga. Kościół przypomina, że we właściwym sensie jedynie Bóg jest Panem. Stworzenie opiera się na prawach natury, które wymykają się kompetencjom człowieka i które powinien on respektować. „Stwórca chciał, aby człowiek obcował z przyrodą jako jej rozumny i szlachetny «pan» i «stróż», a nie jako bezwzględny «eksploatator»" (Redemptor hominis 15). W encyklice Evangelium vitae Papież Jan Paweł II przypomniał:

Panowanie, przekazane przez Stwórcę człowiekowi, nie oznacza władzy absolutnej, nie może też być mowy o wolności «używania» lub dowolnego dysponowania rzeczami. Ograniczenie nałożone od początku na człowieka przez samego Stwórcę i wyrażone w symbolicznym zakazie «spożywania owocu drzewa» (Rdz 2, 16-17) jasno ukazuje, że w odniesieniu do widzialnej natury jesteśmy poddani nie tylko prawom biologicznym, ale także moralnym, których nie można bezkarnie przekraczać ( $\mathrm{nr} 42$ ).

Ostatecznym celem stworzenia jest chwała Boża, która powinna jaśnieć we wszystkich stworzeniach. Misja królewska chrześcijanina nie polega na swawolnym panowaniu nad przyrodą. Obraz króla, który jest użyty na określenie relacji człowieka do stworzenia, nie oznacza monarchy absolutnego, lecz wskazuje na Chrystusa Króla, wiernego sługę Boga, szafarza pokoju i sprawiedliwości, szczególnie wobec biednych i opuszczonych. Podobnie naucza Katechizm Kościoła Katolickiego:

W zamiarze Bożym mężczyzna i niewiasta powołani są do „czynienia sobie ziemi poddaną” jako „administratorzy” Boga. To ich panowanie nie może być samowolnym i niszczącym. Na podobieństwo Stwórcy, ,który kocha wszystko, co istnieje" (Mdr 11, 24) mężczyzna i niewiasta powołani są do uczestnictwa w Bożej Opatrzności w stosunku do stworzeń. Wypływa stąd ich odpowiedzialność w stosunku do świata, który Bóg im powierzył (KKK 373).

Człowiek otrzymał ziemię od Boga w dzierżawę i powinien nią gospodarować mądrze, obchodząc się z nią według Bożych zasad, a nie według kryteriów ludzkiej siły. Człowiek, stworzony na obraz Boży, cieszy się uprzywilejowanym miejscem wśród stworzeń, lecz ten fakt nie oddziela go od całego stworzenia, z którym powinien oddawać cześć Bogu. 
Człowiek stworzony przez Boga przebywał w raju, ciesząc się szczególnymi darami: nadprzyrodzonymi, naturalnymi i pozanaturalnymi. Stan ten nazywamy w teologii stanem świętości i sprawiedliwości pierwotnej. Grzech pierworodny spowodował utratę darów nadprzyrodzonych (przyjaźni z Bogiem, łaski uświęcającej) oraz darów pozanaturalnych, czego obrazem jest wygnanie z rajskiego ogrodu. Człowiek nie utracił jednak władz naturalnych, chociaż i one zostały naruszone i umniejszone. Odkupienie dokonane przez Chrystusa przywróciło dary nadprzyrodzone, ale nie pozanaturalne, które wydaje się, że zostały nieodwracalnie utracone, chociaż obietnica i nadzieja zmartwychwstania je przewyższa.

Katechizm tak opisuje pierwotną integralność i świętość:

Wszystkie wymiary życia ludzkiego były wzmocnione przez tę łaskę. Jak długo człowiek pozostawałby we wspólnocie z Bogiem, tak długo miał być zachowany od umierania ( $R d z 2,17 ; 3,19)$ i cierpienia ( $R d z ~ 3,16)$. Czynnikami konstytutywnymi tego stanu, zwanego «pierwotną sprawiedliwością», były: wewnętrzna harmonia osoby ludzkiej, harmonia między mężczyzną a niewiastą, oraz harmonia między pierwszymi ludźmi a całym stworzeniem (KKK 376). «Panowanie» nad światem, które Bóg od początku powierzył człowiekowi, realizowało się przede wszystkim w samym człowieku jako «panowanie nad samym sobą». Człowiek był całkowicie uporządkowany, ponieważ wolny od potrójnej pożądliwości, która czyni go niewolnikiem przyjemności zmysłowych, chciwości dóbr ziemskich i szukania samego siebie wbrew nakazom rozumu (KKK 377).

\section{Zakończenie}

Powyżej został przedstawiony pobieżny zarys katolickiej nauki o stworzeniu. Doktryna dotycząca stworzenia świata i człowieka jest niezwykle bogata i posiada wiele wątków. Zderza się ona z innymi wizjami świata i stworzenia, które są zaproponowane przez wiedzę potoczną, naukową i filozoficzną. Kościół przypomina podstawowe prawdy wiary związane ze stworzeniem: Bóg jest stwórcą świata i człowieka; stworzenie jest dobre ze swojej natury; świat jest stworzony dla człowieka a człowiek ze względu na Boga; człowiek zgrzeszył i oddalił się od Boga, ale Chrystus przywraca właściwy porządek i daje nadzieję zbawienia.

Należy również przypomnieć, że w ostatnich latach Kościół nieustannie przypomina, że pomiędzy wiarą i naukami przyrodniczymi nie ma i nie powinno być konfliktu. Należy tylko precyzyjnie określić właściwą autonomię płaszczyzn badawczych, które dotyczą tego samego przedmiotu. Prowadzo- 
ny z szacunkiem dialog przyczynia się do lepszego poznania zamysłu Bożego. Wiara i rozum prowadzą ostatecznie do jednego celu, jakim jest wskazanie właściwego miejsca człowieka w świecie i nadania głębokiego sensu ludzkiej egzystencji, czego bez wiary w Boga Stwórcę osiągnąć się nie da.

\section{God and Creation in Catholic Theology (Summary)}

The scientific studies of the creation of the world and of man are of primary significance since they concern the very foundations of human life and give the responses to the basic questions of the sense and purpose of human life. The world was created by the Word of God. The work of creation is attributed to God the Father but all the persons of the Holy Trinity share it. The world was created by love which is God himself and who wills to share it with all the creation.

The purpose of creation is the participation in the Glory of God. God is omnipotent and creates the world ex nihilo together with time and in time. God cares and provides for all his creation, even though it has been corrupted by evil and sin. Man, who was made in the image and likeness of God, is the summit of the Creator's work. As male and female, people are obliged, in the name of God and according to his principles and laws, to care for the world which they have been entrusted with. 